DOI: $10.31866 / 2410-1915.21 .2020 .208253$

UDC 338.48-6:615.8

\title{
WELLNESS CULTURE AS A FACTOR OF FORMATION OF WELLNESS-INDUSTRY
}

\section{Lesia Ustymenko}

PhD in Pedagogic Sciences, Associate Professor, ORCID:0000-0003-2631-1459, ustilesia@gmail.com, Kyiv National University of Culture and Arts, 36, Ye. Konovaltsia St., Kyiv, 01133, Ukraine

\section{For citations:}

Ustymenko, L. (2020). Wellness Culture as a Factor of Formation of Wellness-Industry. Culture and Arts in the Modern World, 21, 182-190. https://doi.org/10.31866/2410-1915.21.2020.208253.

Purpose of the article is an impact analysis of wellness culture on the formation of the wellness industry. The methodological basis of the study is a critical analysis of the basic definitions of cultural and tourism sources for the research of the wellness culture and the wellness industry, an interdisciplinary synthesis of the basic principles of the formation of the wellness culture and the corresponding transformation of the wellness industry, induction and deduction methods, as well as content analysis. Scientific novelty. We have defined and introduced the notions of "wellness culture" and "wellness industry". The essential structural components of the wellness culture and wellness industry in the modern world are determined. Conclusions. The basic social level of the wellness culture and the crucial philosophical principles regarding relations with society and its traditional culture are analysed. The main social functions of the wellness culture are determined. The notions of "wellness industry" and "wellness product" were introduced within the theory of tourism study. The foreign experience usage in the integration of tourism and the "wellness industry", the search for innovative forms of organisation of recreational activities focused on the comprehensive development of the individual is practice-based. It has been found out that the stable functioning of the wellness industry and the development of wellness tourism require a significant transformation of national recreational establishments, effective integration of the tourism and wellness industry, thorough scientific research, expansion and segmentation of the wellness tourism market, taking into account national traditions and economic development of the country, adopting an appropriate range of government programs for its development, raising funding for the wellness industry and modernisation of existing recreational facilities, promotion of wellness tourism to improve the quality of life of the population.

Keywords: wellness culture; wellness industry; wellness product; innovative wellness services; wellness tourism; social functions and levels of wellness culture; modern structure of the wellness industry. 


\section{Introduction}

The development of modern society, the so-called technogenic civilisation, involves not only changes in the paradigm of population recreational needs but also the transformation of the recreational system in general following the demands of society and the cultural and leisure sphere in particular. And such a transformation is taking place, a splendid example of which is the increase of wellness tourism in the recreational market segment, the formation of the wellness industry and its active integration with the tourism industry. Today, the share of tourists who are focused on individually specialised tourism and recreational services, formed under the latest trends in a modern lifestyle with corresponding priorities, increases continuously. A healthy lifestyle, rejuvenation and life enjoyment are among the main priorities of a modern person, and all this is embodied in the term "wellness", which forms a fundamentally new trend of recent recreational activities. It is namely this vector of development determines the whole system of values, ideas, concepts, behaviour patterns and other symbolically significant systems those are factors that form the wellness culture and human behaviour of modern society, as well as products and services aimed at satisfying the corresponding needs. This situation has already led to the emergence and effective functioning of the wellness industry in the developed countries in the world. Moreover, wellness culture has a tendency to active development, creating new entities and models of values.

The analysis of the study of the research issue showed that one of the first who described the philosophy of "wellness", the main factors of its development in society, presenting the corresponding concept in his work Wellness: The History and Development of a Concept, was James William Miller (2005).

American John Travis (977) outlined an extensive range of issues regarding the concept of health improvement and the creation of an appropriate system of institutions that can provide the implementation of new recreational needs of the population, which, in its turn, will provide certain social and economic benefits.

The most significant contribution to the study of general issues about wellness was made by researchers from the USA and Great Britain. In particular, American Paul Zane Pilzer developed and presented a successful concept of wellness business development in his opinion in the period from 2002 to 2007. In his numerous publications, he identifies a new wellness business with updated information about the Wellness Revolution and its active promotion in the recreation sphere, which indicates the beginning of wellness industry integration with corresponding segments of the tourism industry (Pilzer, 2007).

Having won the USA and established itself in the leading European countries, the wellness industry develops steadily in the leading countries of Asia, Australia and New Zealand. Today, wellness programs are sold all over the world as a panacea for preventive medicine and are an important business segment. This is confirmed by the fact that in almost every resort complex in China wellness centres of traditional methods are created and functioned actively, and modern wellness complexes have been formed in urban environments. Fang 
Yang (2009) notes that the wellness industry is a new stimulus for the Chinese economic development.

Despite the presence of an important body of researches and publications on various aspects of the development of wellness activities, a significant component remains studied insufficiently, which can be embodied in the concept of "wellness culture", and the totality of modern foreign experience on its impact on the wellness industry.

\section{Purpose of the article}

The purpose of the study is to analyse the impact of wellness culture on the formation of the wellness industry, which determines the following range of tasks:

- to review publications on the topic under study;

- to analyse the main definitions and directions of research;

- to substantiate and introduce the concepts of "wellness culture" and "wellness industry" into scientific use;

- to identify the main structural components of the wellness culture and wellness industry in the modern world;

- to describe the state of wellness industry formation in Ukraine.

\section{Main research material}

The term "wellness" comes from the English "be well", which literally means "feel good" or "well-being". Today, the notion of "wellness" is a concept of a healthy lifestyle based on a combination of physical and mental health, healthy eating, reasonable physical activity and the rejection of bad habits ("Wellness", 1971).

The main task of wellness activities is to harmonise the psychological and physical condition of a person, prevention and prophylaxis of diseases, as well as signs of ageing, both external and internal. In modern society, wellness is a philosophy of human well-being in all spheres of life: spiritual and physical, and successful social realisation. According to the generally accepted stereotype, the one who lives by this philosophy is successful, full of energy, optimistic and vigorous, regardless of age. He pays attention to the appearance of his body, adheres to the healthy lifestyle principles, uses moderate physical activity, can enjoy life.

Some of the basic wellness philosophy principles are:

- movement;

- mental activity;

- relaxation and harmony;

- beauty and body care;

- balanced diet.

In 1959, the American physician Halbert L. Dunn introduced the concept of "wellness" and was the first who formulated the basic healthy lifestyle principles. In the 1960s, wellness became very popular at first in professional circles 
among successful and wealthy people, and later in wide circles of American society, owing to numerous publications by Halbert Dunn, John Travis, Donald Ardell and Gerhart Hettler.

Since stress has become a common negative phenomenon in the life of a modern person, which has a constant tendency to increase, a number of researchers and specialists in the recreation sphere began to study and develop programs for psychological recovery. Stephen F. Myler in the article Wellness \& Psychology considered the concept of health in terms of mental health, where the psychological state is an important component of health not only of the individual but also the whole nation, so wellness activities should be comprehensive as much as possible, starting with the formation of social priorities and stereotypes of behaviour to the suggestion of a balanced psychological approach to well-being and long-term stability (Myler, 2014).

According to the trends of wellness activities in recent decades, it also includes the sphere of physical culture, as it is a concept of a broader meaning. Thus, modern wellness is a comprehensive use of health improvement techniques consisting of dietology, rehabilitation programs, psychological health improvement, functional training, rejuvenation and beauty programs, various SPA-procedures aimed at restoring, developing and harmonising the psychophysical state of a person, optimising physical and mental health. The modern leading wellness concept pays considerable attention to the formation of healthy habits, which requires numerous publications and activities to form a healthy lifestyle. The above-mentioned factors, in their turn, led to the emergence of a large segment of social culture, namely wellness culture.

As it is known, social culture is the attitude of people to each other, the system of statuses and social institutions. Social behaviour and artefacts (social and material culture) are interpreted as objectified products of ideal normative systems and knowledge systems of various kinds, which are spiritual culture. The separation of social culture allows combining material and spiritual cultures in the context of social science researches. Accordingly, within the social culture, the wellness culture was formed as a separate segment that covers all social levels, namely:

- social wellness culture;

- collective wellness culture (organisation or corporation);

- individual wellness culture.

According to the above mentioned, it is expedient to introduce the concept of "wellness culture" into scientific use. Thus, wellness culture is a set of spiritual and material values created by society during a particular historical period as a result of satisfaction of the society recreational needs and the acquired set of rules and norms of wellness activities within society for its preservation and implementation.

Today, wellness culture performs the following social functions:

- the cognitive function provides an opportunity to record, transfer and explore the achievements of humanity in this sphere of activity;

- the informative function of wellness culture transmits the accumulated social experience; 
- the regulatory function is realised through the implementation of certain norms of behaviour;

- the axiological function of wellness culture is to form certain value orientations, moral attitudes and tastes in a person;

- the worldview function is manifested in the fact that it synthesises a system of factors of the mental and spiritual world of a person (cognitive, emotional and sensory, evaluative, volitional, and so on) into an integral and complete form;

- the educational function of wellness culture is expressed in the fact that it is a factor of self-development of humankind.

In a broad sense, the wellness industry is a system of institutions and enterprises that provide the population with a wide range of various (traditional and innovative) recreational services.

The experience of studying the basic principles of organisation and functioning of the wellness industry of the leading countries in the world allows distinguishing the following main structural components common with the tourism industry. tion:

1. Establishments and areas of recreational and health-improving direc-

- specialised medical and preventive treatment facility;

- thermal complexes;

- equipped beaches;

- facilities and areas for physical culture and sports;

- tracking areas;

- pump rooms of mineral waters;

- wellness clubs;

- SPA complexes, centres and areas.

2. Companies providing accommodation services:

- hotels, motels, campsites, boarding houses;

- sanatoriums, preventoriums;

- tourist bases, rest homes, shelters and others.

3. Food companies:

- restaurants, canteens;

- cafes, bars;

- fast food companies.

4. Companies providing transport services:

- car companies;

- railway departments;

- river and sea transport companies.

5. Travel companies for the development and selling of wellness products:

- travel companies for the development of wellness products;

- travel companies for the sale of wellness products.

6. Leisure companies:

- culture and recreation parks;

- special interest clubs;

- entertainment establishments. 
The establishments as mentioned above and companies provide the population with similar wellness services, the complex of which forms a wellness product. There are clear criteria for evaluation of wellness industry activities, where staff qualification are one of the basic requirements for a successful image of a wellness company and is important for further optimisation of the efficiency of its activity, providing quality wellness services and wellness product. For high-quality training, it is absolutely necessary to study the basics of the wellness activities theory both in the general context and in specialised training within the regularities of modern tourist and recreational needs of the population and create a base for mastering the basic forms and methods of wellness activities.

Since two-thirds of the tourism and wellness industry establishments are joint, and the activities of the establishments are interrelated, and sometimes are interdependent, it is considered appropriate that educational establishments that train specialists in the tourism industry, start training specialists for the wellness industry in a general or a separate speciality. The reason for this is a growing number of wellness industry establishments, expansion of the range and number of wellness services. Today, for successful and effective recreational activities, the episodic descriptive sources of practical experience are insufficient, it is necessary to form a theoretical basis for:

- disclosure of wellness activities content;

- descriptions of the basic concepts and definitions of wellness activities;

- the modern structure of wellness industry;

- analysis of social functions of tourism of wellness activities;

- wellness product classification;

- descriptions of advanced methods and forms of wellness activities;

- analysis of the interrelation between tourism and wellness activities;

- study of the process of organisation and functioning of the wellness industry in the modern world;

- national features and specifics of international wellness tourism.

While the wellness industry develops in the world and integrates actively with the tourism industry, in Ukraine, it is still in the process of formation, although some of its components are already quite well developed. In general, this can be said about fitness centres, SPA centres, and rejuvenation programs. As for the restructuring of the national health resort and sanatorium industry, it is hampered by a number of factors, such as insufficient funding of the sector, which, in its turn, is caused by low solvency of the majority of the national population, because investors need profit that requires mass consumers, which we cannot observe on the Ukrainian market of wellness services today since the main directions of wellness activity are quite expensive, that is today only wealthy segments of the population can afford them regularly.

Health-improving, relaxation or aesthetic SPA-packages for a few days have gained popularity in the European market of wellness services long ago. This form of activity of recreational facilities is attractive to customers regardless of the season. With the emergence of alternatives to health tourism, the period of stay in wellness facilities becomes more flexible, does not provide fixed cours- 
es of treatment, in contrast to medical and health-improving ones. Wellness tourism is characterised by much less dependence on seasonal and crisis trends (Tooman, 2009).

Today, one of the new forms of activity for most Ukrainian resort establishments which do not require significant reorganisation can be wellness weekendtour. In Ukraine, the recreational facilities located only near large cities, usually regional centres and the capital, have relatively good opportunities for wellness weekend-tours. Modern tourists have become more discerning, unpredictable in their tastes and priorities. And this situation requires that managers of tourist and recreational companies make strategic decisions on conceptual changes and find ways to satisfy new consumer needs (Ustymenko, 2016).

\section{Conclusions}

Having analysed the influence of wellness culture on the formation of the wellness industry, we can ascertain that this is a transition to a new stage in the development of the recreational sphere, which, in its turn, represents an appropriate level of understanding of the quality of life, a conscious attitude to oneself and society. Wellness culture organically combines the spiritual practices of the East and high technology, modern methods of health improvement, the latest developments in the spheres of nutrition, cosmetology, medicine, leisure and tourism.

At the present stage of development of society, wellness culture is an important and necessary phenomenon that provides the implementation of cognitive, recreational, economic, educational and entertainment functions of tourism. Wellness culture influences significantly on the formation of value orientations of a modern person regarding recreation, forms his recreational needs and, accordingly, ensures the development of wellness tourism and the necessary transformations of the wellness industry.

In its turn, the stable functioning of the wellness industry and the development of wellness tourism require a significant transformation of national recreational facilities, effective integration of tourism and wellness industry, thorough research, expansion and segmentation of the wellness tourism market depending on traditions and economic development of the country; adoption of the corresponding range of state programs for its development; attracting investment for the modernisation of recreational facilities; popularisation of wellness tourism to improve the quality of life of the population.

\section{References}

Fang, Y. (2009, October 26). China has the greatest opportunity to do wellness all over the world. China View [in English].

Miller, J. W. (2005). Wellness: The History and Development of a Concept. Spektrum Freizeit, 27(1), 84-106 [in English].

Myler, S. F. (2014). Wellness and Psychology. https://www.academia.edu/7577289/ Wellness_and_Psychology [in English]. 
Pilzer, P.Z. (2007). The New Wellness Revolution: How to Make a Fortune in the Next Trillion Dollar Industry (2nd ed.). John Wiley \& Sons [in English].

Tooman, H. (2009). Wellness - A New Perspective for Leisure and Tourism. Wellness Philosophy. https://web.archive.org/web/20140106140728/http://pc.parnu.ee/ htooman/ Teemade_esitlused/3_\%20The\%20Wellness\%20Concept.pdf [in English].

Travis, J. (1977). Wellness Workbook for Health Professionals. Wellness Publications [in English].

Ustymenko, L. (2016). Weekend tourism as a cultural phenomenon. Culture and Art in the Modern World, 17, 11-16 [in English].

Ustymenko, L. M., \& Bulhakova, N. V. (2019). Kulturno-rekreatsiini potreby v konteksti turyzmu [Cultural and recreational needs in the context of tourism]. National Academy of Managerial Staff of Culture and Arts Herald, 2, 226-230 [in Ukrainian].

Wellness. (1971). In J. A. H. Murray (Ed.), The Compact Edition of the Oxford English Dictionary (Vol. 2, p. 3738). Oxford University Press [in English].

\section{WELLNESS-КУЛЬТУРА ЯК ЧИННИК ФОРМУВАННЯ WELLNESS-IНДУСTPIÏ}

\section{Устименко Леся Миколаївна}

Кандидат педагогічних наук, ORCID: 0000-0003-2631-1459, ustilesia@gmail.com, Київський національний університет культури і мистецтв, Київ, Україна

Метою статті $є$ аналіз впливу wellness-культури на формування wellness-індустрії. Методологічну основу дослідження становлять критичний аналіз основних дефініцій культурологічних і туризмознавчих джерел щодо дослідження wellness-культури та wellness-індустрії, міждисциплінарний синтез основних принципів формування wellness-культури та відповідної трансформації wellness-індустрії, методи індукції та дедукції, а також контент-аналіз. Наукова новизна. Визначено та введено до наукового обігу поняття «wellness-культура» та «wellness-індустрія». Окреслено основні структурні складові wellness-культури та wellness-індустрії в сучасному світі. Висновки. Проаналізовано основні соціальні рівні wellness-культури та найбільш вагомі світоглядні принципи щодо взаємовідносин із суспільством та його традиційною культурою. Сформульовано основні суспільні функції wellness-культури. Введено до наукового обігу теорії туризмознавства поняття «wellness-індустрія» та «wellness-продукт». Обгрунтовано доцільність використання закордонного досвіду інтеграції туристичної та wellness-індустрії, пошуку інноваційних форм організації рекреаційної діяльності, орієнтованих на всебічний розвиток особистості. 3’ясовано, що для стабільного функціонування wellness-індустрії та розвитку wellness-туризму необхідні суттєва трансформація вітчизняних рекреаційних закладів, ефективна інтеграція туристичної та wellness-індустрії, грунтовні наукові дослідження, розширення та сегментація ринку wellness-туризму, врахування національних традицій та економічного розвитку країни, 
прийняття відповідного кола державних програм щодо його розвитку, залучення інвестицій до wellness-індустрії та модернізація існуючих рекреаційних закладів, популяризація wellness-туризму з метою підвищення якості життя населення.

Ключові слова: wellness-культура; wellness-індустрія; wellness-продукт; інноваційні wellness-послуги; wellness-туризм; суспільні функції та рівні wellnessкультури; сучасна структура wellness-індустрії.

\section{WELLNESS-КУЛЬТУРА КАК ФАКТОР ФОРМИРОВАНИЯ WELLNESS-ИНДУСТРИИ}

\section{Устименко Леся Николаевна}

Кандидат педагогических наук, ORCID:0000-0003-2631-1459, ustilesia@gmail.com, Киевский национальный университет культуры и искусств, Киев, Украина

Целью статьи является анализ влияния wellness-культуры на формирование wellness-индустрии. Методологическую основу исследования составляют критический анализ основных дефиниций культурологических и туризмоведческих источников по исследованию wellness-культуры и wellness-индустрии, междисциплинарный синтез основных принципов формирования wellness-культуры и соответствующей трансформации wellness-индустрии, методы индукции и дедукции, а также контентанализ. Научная новизна. Определены и введены в научный оборот понятия «wellness-культура» и «wellness-индустрия». Очерчены основные структурные составляющие wellness-культуры и wellness-индустрии в современном мире. Выводы. Проанализированы основные социальные уровни wellness-культуры и наиболее значимые мировоззренческие принципы относительно взаимоотношений с обществом и его традиционной культурой. Сформулированы основные общественные функции wellness-культуры. Введены в научный оборот теории туризмоведения понятия «wellness-индустрия» и «wellness-продукт». Обоснована целесообразность использования зарубежного опыта интеграции туристической и wellness-индустрии, поиска инновационных форм организации рекреационной деятельности, ориентированных на всестороннее развитие личности. Выяснено, что для стабильного функционирования wellness-индустрии и развития wellness-туризма необходимы существенная трансформация отечественных рекреационных заведений, эффективная интеграция туристической и wellness-индустрии, основательные научные исследования, расширение и сегментация рынка wellness-туризма, учет национальных традиций и экономического развития страны, принятие соответствующего круга государственных программ по его развитию, привлечение инвестиций в wellness-индустрию и модернизация существующих рекреационных учреждений; популяризация wellnessтуризма с целью повышения качества жизни населения.

Ключевые слова: wellness-культура; wellness-индустрия; wellness-продукт; инновационные wellness-услуги; wellness-туризм; общественные функции и уровни wellness-культуры; современная структура wellness-индустрии. 